\title{
CAMBIO DE DIRECTOR
}

Después de seis años de ardua y eficiente labor, nuestro Director de publicaciones decidió presentar su renuncia a la Mesa Directiva del Instituto, "para retirarse al descanso". Yo, como Presidente del Instituto, hice lo humanamente posible para que Carlos García-Prada nos acompañara todavía un trecho más. Pero todo fué inútil. Yo sabía que el descanso de nuestro Director "era pelear"; pero como sus futuras batallas iban a ser en esa zona espiritual en que todos debemos ceñir espada, por fin le encontré razón. Ahora, en nombre de la Mesa Directiva y de todos los socios del Instituto, quiero darle las gracias por su obra intelectual, humana, moderna; por su sacrificio alegre, por su sonrisa sobre la inquietud y la duda. Quienes sabemos lo que significa la tarea en que Carlos estaba empeñado, podemos estrecharle la mano con orgullo: la mano heroica. Y aun en la renuncia, le sabemos dinámico, optimista, nuestro.

Y ahora empuña el timón otro de los fundadores del Instituto, Julio Jiménez Rueda; con su Dirección la Revista irá segura, y nosotros confiados, porque a su capacidad intelectual y técnica agrega Jiménez Rueda una $f e$ inquebrantable en los ideales de nuestra institución.

Al amigo García-Prada nuestro recuerdo constante, en el agradecimiento por su labor cumplida; al amigo Jiménez Rueda, nuestro aplauso constante en la esperanza de las faenas por venir.

A. TORRES-RIOSECO 
